\title{
To Compare Isobaric $0.5 \%$ Levobupivacaine with Isobaric $0.5 \%$ Ropivacaine in Brachial Plexus Block For Elective Upper Limb Surgery.
}

\author{
Nagesh Mudgal ${ }^{1}$, Monika Saini ${ }^{2}$ \\ ${ }^{1}$ Senior Resident, Department of Anaesthesiology, Index Medical College Hospital \& Research Centre, Indore, ${ }^{2}$ Assistant Professor, Department of \\ Anaesthesiology, Index Medical College Hospital \& Research Centre, Indore.
}

\section{Abstract}

Background: The study entitled "To compare the effects of $0.5 \%$ Levobupivacaine with $0.5 \%$ Ropivacaine for brachial plexus block in elective upper limb surgeries" was conducted at Bombay Hospital, Indore (M.P.). Subjects and Methods: The study entitled "To compare the effects of $0.5 \%$ Levobupivacainewith $0.5 \%$ Ropivacaine for brachial plexus block in elective upper limb surgeries" was conducted at Bombay Hospital, Indore (M.P.) Sixty patients aged between 18yrs and 60yr physical status ASA grade 1 and ASA grade 2 undergoing elective upper limb surgeries were included in the study. Results: Mean onset time of sensory block was rapid ingroup L (11.203 \pm 1.58$)$ minutes as compared to group $\mathrm{R}(13.62 \pm 1.544)$ minutes which is statistically significant with $\mathrm{p}$ value $<0.05$. Mean duration of sensory block wassignificantly prolonged in group L $(12.07 \pm 1.09)$ hours as compared to group $\mathrm{R}(10.840 \pm 1.713)$ hours which is statistically significant with $\mathrm{p}$ value $<$ 0.05. Mean duration of motor block was significantly prolonged in group L (11.137 \pm 1.513$)$ hours as compared to group R(10.063 \pm 1.209$)$ hours which is statistically significant with $\mathrm{p}$ value $<0.05$. Mean onset time of motor block was rapid in group L (17.370 $\square 1.618)$ minutes as compared to group R (18.977 $\square 1.375)$ minutes which is statistically significant with p value $<0.05$. Mean duration of Analgesia motor block was significantly prolonged in group L (15.073 $\square .902)$ hours as compared to group $\mathrm{R}(12.663 \square 1.608)$ hours which is statistically significant with $\mathrm{p}$ value <0.05. Conclusion: To conclude the study, we observed Levobupivacaine 0.5\% having better profile in comparison to ropivacaine $0.5 \%$ in having Faster onset of sensory and motor blockade, Prolonged duration of sensory and motor blockade, Prolonged duration of analgesia, Levobupivacaine should be considered for peripheral nerve block when postoperative analgesia is a concern but not when an early return of motor function is desired in postoperative period for upper limb elective surgeries.

Keywords: Isobaric, Ropivacaine, Levobupivacain, Upper Limb\& Surgery.

Corresponding Author: Dr. Monika Saini, Assistant Professor, Department of Anaesthesiology, Index Medical College Hospital \& Research Centre, Indore

Received: June 2019

Accepted: June 2019

\section{Introduction}

Anaesthesia as a subject by itself originated in an endeavor to offer pain relief to the patient during surgical procedure. Providing perioperative and postoperative analgesia without any systemic adverse effects is an uphill task in hands of anesthesiologist. ${ }^{[1]}$

Bupivacaine, the widely used local anesthetic in regional anesthesia is available in a commercial preparation as a racemic mixture (50:50) of its two enantiomers, levobupivacaine, $\mathrm{S}(-)$ isomer and dextrobupivacaine, $\mathrm{R}(+)$ isomer. Severe central nervous system (CNS) and cardiovascular adverse reactions reported in the literature after inadvertent intravascular injection or intravenous regional anesthesia have been linked to the $\mathrm{R}(+)$ isomer of bupivacaine. The levorotatory isomers were shown to have a safer pharmacological profile with less cardiac and neurotoxic adverse effects. ${ }^{[2-4]}$

\section{Subjects and Methods}

The study entitled "To compare the effects of $0.5 \%$
Levobupivacainewith $0.5 \%$ Ropivacaine for brachial plexus block in elective upper limb surgeries" was conducted at Bombay Hospital, Indore (M.P.) from Jan 2018 to May 2018. Sixty patients aged between $18 y$ rs and $60 y$ physical status ASA grade 1 and ASA grade 2 undergoing elective upper limb surgeries were included in the study after ethical clearance from the college ethical committee.

\section{Study Population}

A minimum of 60 patients admitted to Bombay Hospital, Indore satisfying the inclusion and exclusion criteria and undergoing elective upper limb surgery were included in the study.

\section{Sample Size}

Sample size calculation revealed that 20 patients per group were required to detect a difference of 2.4 Minutes in mean value of Onset time of Sensory Block between two groups, at an alpha of 0.05 with power of $80 \%$.

$\mathrm{P}$ values $<0.05$ was considered to indicate statistical significance. Hence, we intended to take more than 20 
patients per group.

Sixty patients aged between $18 \mathrm{yrs}$ and $60 \mathrm{yr}$ physical status ASA grade 1 and ASA grade 2 undergoing elective upper limb surgeries were included in the study. Each patient was visited pre-operatively and the procedure explained and written informed consent was obtained. Complete blood count, blood grouping, blood sugar, bleeding time, clotting time, blood urea, serum creatinine, serum electrolytes(sodium, potassium, chloride), chest x-ray, ECG were done.

\section{Inclusion Criteria}

- Patients aged between 18yrs and 60yrs

- American society of Anaesthesiologists (ASA) physical status I - II.

- Patient height more than $150 \mathrm{~cm}$.

- Patients weighing more than $50 \mathrm{~kg}$

- Scheduled for elective upper limb surgeries

\section{Exclusion Criteria}

- Patient refusal for procedure

- Emergency upper limb surgeries

- Traumatic nerve injury

- History of respiratory disorders

- History of neuromuscular diseases

- History of cardiovascular diseases

- Neurological deficits involving brachial plexus

- Any bleeding disorder or patient on anticoagulants

- Hepatic or Renal failure

- Pregnant women

- Known allergy to local anaesthetic agents

- Local infection at the injection site

- Patients on any sedatives or antipsychotics

\section{Results}

Table 1: Comparison of mean Onset of Sensory Blockage between the two groups

\begin{tabular}{|l|l|l|l|l|}
\hline $\begin{array}{l}\text { Onset of } \\
\text { Sensory } \\
\text { Blockage } \\
\text { (min) }\end{array}$ & Group L & Group R & $\begin{array}{l}\text { 't' } \\
\text { Value }\end{array}$ & $\begin{array}{l}\text { P } \\
\text { value }\end{array}$ \\
\hline Mean \pm SD & $11.203 \pm 1.589$ & $13.620 \pm 1.544$ & $\begin{array}{l}-5.973, \\
\text { df }=58\end{array}$ & $\begin{array}{l}0.000, \\
\text { S }\end{array}$ \\
\hline
\end{tabular}

Mean onset time of sensory block was rapid ingroup $\mathrm{L}$ $(11.203 \pm 1.58)$ minutes as compared to group $\mathrm{R}$ $(13.62 \pm 1.544)$ minutes which is statistically significant with $\mathrm{p}$ value $<0.05$.

Table 2: Comparison of mean Onset of Motor Blockage between the two groups.

\begin{tabular}{|l|l|l|l|l|}
\hline $\begin{array}{l}\text { Onset of } \\
\text { Motor } \\
\text { Blockage } \\
\text { (min) }\end{array}$ & Group L & Group R & 't' Value & $\begin{array}{l}\text { P } \\
\text { Value }\end{array}$ \\
\hline Mean \pm SD & $17.370 \pm 1.618$ & $18.977 \pm 1.375$ & $\begin{array}{l}- \\
4.143, \mathrm{df}=58\end{array}$ & $\begin{array}{l}0.000, \\
\mathrm{~S}\end{array}$ \\
\hline
\end{tabular}

Unpaired " $\mathrm{t}$ " test applied. $\mathrm{P}$ value $<0.05$ was taken as statistically significant

Mean onset time of motor block was rapid in group $\mathrm{L}$ $(17.370 \pm 1.618)$ minutes as compared to group $\mathrm{R}$ (18.977 \pm 1.375$)$ minutes which is statistically significant with $\mathrm{p}$ value $<0.05$

Table 3: Comparison of mean Duration of Sensory Block between the two groups

\begin{tabular}{|l|l|l|l|l|}
\hline $\begin{array}{l}\text { Duration of } \\
\text { Sensory } \\
\text { Blockage (min) }\end{array}$ & Group L & Group R & $\begin{array}{l}\text { 't' } \\
\text { Value }\end{array}$ & $\begin{array}{l}\mathbf{P} \\
\text { value }\end{array}$ \\
\hline Mean \pm SD & $12.070 \pm 1.093$ & $10.840 \pm 1.713$ & $\begin{array}{l}3.315, \\
\mathrm{df}=58\end{array}$ & $\begin{array}{l}0.002, \\
\mathrm{~S}\end{array}$ \\
\hline
\end{tabular}

Unpaired,"t'test applied. $\mathrm{P}$ value $<0.05$ was taken as statistically significant

Mean duration of sensory block was significantly prolonged in group L (12.07 \pm 1.09$)$ hours as compared to group $\mathrm{R}(10.840 \pm 1.713)$ hours which is statistically significant with $\mathrm{p}$ value $<0.05$.

Table 4: Comparison of mean Duration of Motor Block between the two groups

\begin{tabular}{|l|l|l|l|l|}
\hline $\begin{array}{l}\text { Duration of } \\
\text { Motor } \\
\text { Blockage (min) }\end{array}$ & Group L & Group R & $\begin{array}{l}\text { 't' } \\
\text { Value }\end{array}$ & $\begin{array}{l}\text { P } \\
\text { value }\end{array}$ \\
\hline Mean \pm SD & $11.137 \pm 1.513$ & $10.063 \pm 1.209$ & $\begin{array}{l}3.035, \\
\text { df=58 }\end{array}$ & $\begin{array}{l}0.004, \\
\mathrm{~S}\end{array}$ \\
\hline
\end{tabular}

Mean duration of motor block was significant lyprolonged in group L $(11.137 \pm 1.513)$ hours as compared to group $\mathrm{R}(10.063 \pm 1.209)$ hours which is statistically significant with $\mathrm{p}$ value $<0.05$.

Table 5: Comparison of mean Duration of Analgesia between the two groups

\begin{tabular}{|l|l|l|l|l|}
\hline $\begin{array}{l}\text { Duration of } \\
\text { Motor } \\
\text { Blockage (min) }\end{array}$ & Group L & Group R & $\begin{array}{l}\text { 't' } \\
\text { Value }\end{array}$ & $\begin{array}{l}\text { P } \\
\text { value }\end{array}$ \\
\hline Mean \pm SD & $15.073 \pm .902$ & $12.663 \pm 1.608$ & $\begin{array}{l}7.156, \\
\text { df=58 }\end{array}$ & $\begin{array}{l}0.000, \\
\text { S }\end{array}$ \\
\hline
\end{tabular}

Mean duration of Analgesia motor block was significant lyprolonged in group L (15.073 $\square .902)$ hours as compared to group $\mathrm{R}(12.663 \square 1.608)$ hours which is statistically significant with $\mathrm{p}$ value $<0.05$.

\section{Discussion}

Onset of sensory block: [Table 1] shows comparison of mean onset of sensory blockage between the two groups. Mean onset time of sensory block was rapid in group L (11.203 \pm 1.58$)$ minutes as compared to group $\mathrm{R}($ $13.62 \pm 1.544)$ minutes which is statistically significant with $\mathrm{p}$ value $<0.05$.

Our observations are in accordance with the findings of Mageswaran R et al. ${ }^{[5]}$ (2010), who observed the mean onset time (SD) for sensory blockwithropivacaine was $13.5 \pm 2.9$ minutes compared to levobupivacaine at $11.1 \pm 2.6$ minutes $(\mathrm{p}$ $=0.003$ ).

Similar results were found in the study by Kulkarni SB et al. ${ }^{[6]}$ (2016), who observed the onset of sensory blockade was rapid (8.6 \pm 1.522$)$ minutes in levobupivacaine group than in ropivacaine group $(9.533 \pm 1.656)$ minutes which was statistically significant ( $\mathrm{p}$ value $=0.027$ ).

Our observations are at variance with the findings of 
PreranaPMankad et al. ${ }^{[7]}$ (2016) and Li A. et al. ${ }^{[8]}$ (2017), observed no statisticallysignificant difference in onset of sensory block between Levobupivacaine $0.5 \%$ and Ropivacaine $0.5 \%$ ( $\mathrm{p}$ value $>0.05$ )

Our observations are not supported by study of Anuja A Rathore (2017) ${ }^{[9]}$ observed the onset of sensory blockade was shorter $(8.24 \pm 2.26)$ minutes inopivacainegroupthan in levobupivacaine group $(10.6 \pm 3.19)$ minutes which was statistically significant $(\mathrm{p}$ value $=0.015$ )

Duration of sensory block: [Table 2] shows comparison of mean duration of sensory blockage between the two groups. Mean duration of sensory block was significantly prolonged in group L $(12.07 \pm 1.09)$ hours as compared to group $\mathrm{R}$ $(10.840 \pm 1.713)$ hours which is statistically significant with $p$ value $<0.05$.

Our observations are in accordance with the findings of Prerana P Mankad et al. ${ }^{[7]}$ (2016) observed the duration of sensory blockade wassignificantly prolonged $(10.93 \pm 1.363)$ hours in levobupivacaine group than in ropivacaine group $(8.67 \pm 1.093)$ hours which was statistically significant ( $\mathrm{p}$ value $<0.001$ )

Similar results were found by Kulkarni SB et al. ${ }^{[6]}$ (2016), who observed the duration of sensory blockade was significantly prolonged $(12.116 \pm 0.715)$ hours in levobupivacaine group than in ropivacaine group (11.266 \pm 0.751$)$ hours which was statistically significant ( $\mathrm{p}$ value $=0.0001$ ).

Onset of motor block: shows comparison of mean onset of motor blockage between the two groups. Mean onset time of motor block was rapid in group L $(17.37 \pm 1.618)$ minutes as compared to group $\mathrm{R}(18.977 \pm 1.375)$ minutes which is statistically significant with $\mathrm{p}$ value $<0.05$.

Our observations are in accordance with the findings of Mageswaran R et al. ${ }^{[5]}$ (2010). The onset time for motor block was $19.0 \pm 2.7$ minutes in ropivacaine group compared to $17.1 \pm 2.6$ minutes $(\mathrm{p}=0.013)$ in levobupivacaine group which is statistically significant with $\mathrm{p}$ value $<0.05$.

Duration of motor block: shows comparison of mean duration of motor blockage between the two groups. Mean duration of motor block was significantly prolonged in group $\mathrm{L}(11.137 \pm 1.513)$ hours as compared to group $\mathrm{R}($ $10.063 \pm 1.209$ ) hours which is statistically significant with $\mathrm{p}$ value $<0.05$.

Our observations are in accordance with the findings of Prerana P Mankad et al. ${ }^{[7]}$ (2016) observed the duration of motor blockade was significantly prolonged $(10.87 \pm 1.137)$ hours in levobupivacaine group than in ropivacaine group $(7.13 \pm 1.252)$ hours which was statistically significant ( $p$ value $<0.05$ ).

Duration of analgesia: shows comparison of mean duration of analgesia or need of rescue analgesia between the two groups. Mean duration of analgesia was significantly prolonged in group L $(15.073 \pm 0.902)$ hours as compared to group $\mathrm{R}(12.663 \pm 1.608)$ hours which is statistically significant with $\mathrm{p}$ value $<0.05$.

Our observations are supported by Prerana P Mankad et al. ${ }^{[7]}$ (2016), they found the duration of analgesia was significantly prolonged $(12.56 \pm 1.30)$ hours in levobupivacaine group than in ropivacaine group $(9.93 \pm 1.7)$ hours which was statistically significant ( $\mathrm{p}$ value $<0.05$ ).

\section{Conclusion}

To conclude the study, we observed Levobupivacaine $0.5 \%$ having better profile in comparison to ropivacaine $0.5 \%$ in having Faster onset of sensory and motor blockade, Prolonged duration of sensory and motor blockade, Prolonged duration of analgesia, Levobupivacaine should be considered for peripheral nerve block when postoperative analgesia is a concern but not when an early return of motor function is desired in postoperative period for upper limb elective surgeries.

\section{References}

1. McLeod GA, Burke D. Levobupivacaine. Anaesthesia. 2001;56:331-41.

2. Casati A, Baciarello M. Enantiomeric local anesthetics: Can ropivacaine and levobupivacaine improve our practice? Curr Drug Ther. 2006;1:859 .

3. Huang YF, Pryor ME, Mather LE, Veering BT. Cardiovascular and central nervous system effects of intravenous levobupivacaine and bupivacaine in sheep. AnesthAnalg. 1998;86:797-804.

4. Morrison SG, Dominguez JJ, Frascarolo P, Reiz S. A comparison of the electrocardiographic cardiotoxic effects of racemic bupivacaine, levobupivacaine, and ropivacaine in anesthetized swine. AnesthAnalg. 2000;90:1308-14.

5. Mageswaran R1, Choy YC. Comparison of $0.5 \%$ ropivacaine and $0.5 \%$ levobupivacaine for infraclavicular brachial plexus block. Med J Malaysia. 2010 Dec;65(4):300-3.

6. Kulkarni SB, Pimpare M, Govardhane BT. Comparison of levobupivacaine with ropivacaine for supraclavicular brachial plexus block. Int J Res Med Sci 2016;4:3789-96.

7. Mankad PP, Makwana JC, Shah BJ. A comparative study of $0.5 \%$ ropivacaine and $0.5 \%$ levobupivacaine in supraclavicular brachial plexus block. Int J Med Sci Public Health 2016;5:74-79.

8. Selander D. Catheter technique in axillary plexus block: presentation of anew method. ActaAnaesthesiologicaScandinavica. 1977;21 (4): 324-9.

9. Rathore AA, Bhosale JP. A comparative double blinded study of levobupivacaine and ropivacaine in USG guided supraclavicular brachial plexus block. MedPulse-International Medical Journal. March 2017;4(3):320-324.

Copyright: (c) the author(s), publisher. Academia Anesthesiologica International is an Official Publication of "Society for Health Care \& Research Development". It is an open-access article distributed under the terms of the Creative Commons Attribution Non-Commercial License, which permits unrestricted non-commercial use, distribution, and reproduction in any medium, provided the original work is properly cited.

How to cite this article: Mudgal N, Saini M.To Compare Isobaric 0.5\% Levobupivacaine with Isobaric 0.5\% Ropivacaine in Brachial Plexus Block For Elective Upper Limb Surgery. Acad. Anesthesiol. Int. 2019;4(2):58-60.

DOI: dx.doi.org/10.21276/aan.2019.4.2.15

Source of Support: Nil, Conflict of Interest: None declared. 